\title{
Correction to: New molecular biomarkers in precise diagnosis and therapy of type 2 diabetes
}

\section{S. Mandal ${ }^{1}$}

Published online: 2 December 2019

(C) IUPESM and Springer-Verlag GmbH Germany, part of Springer Nature 2019

\section{Correction to: Health and Technology} https://doi.org/10.1007/s12553-019-00385-6

The article "New molecular biomarkers in precise diagnosis and therapy of type 2 diabetes," written by S. Mandal, was originally published electronically on the publisher's Internet portal (currently SpringerLink) on October 26, 2019, with open access. With the author(s)' decision to step back from Open Choice, the copyright of the article changed on
November 30, 2019, to (C) IUPESM and Springer-Verlag GmbH Germany, part of Springer Nature 2019, and the article is forthwith distributed under the terms of copyright.

The original article has been corrected.

\section{Compliance with ethical standards}

Conflict of interest The authors declare that they have no conflict of interest.

The online version of the original article can be found at https://doi.org/ 10.1007/s12553-019-00385-6

S. Mandal

mandalshakira@yahoo.co.uk

1 Department of Natural Sciences in Pharmacy, Faculty of Pharmacy, University of Sarajevo, Sarajevo, Bosnia and Herzegovina 